\title{
Diallyl disulfide effect on the invasion and migration ability of HL-60 cells with a high expression of DJ-1 in the nucleus through the suppression of the Src signaling pathway
}

\author{
RAN LIU ${ }^{1,2 *}$, YE-NING YANG ${ }^{3 *}$, LAN YI $^{1}$, JING QING $^{1}$, QING-YE LI ${ }^{1}$, \\ WEN-SONG WANG ${ }^{1}$, JUAN WANG ${ }^{1}$, YU-XIAN TANG ${ }^{1}$ and HUI TAN ${ }^{1}$
}

${ }^{1}$ Cancer Research Institute, Key Laboratory of Tumor Cellular and Molecular Pathology, College of Hunan Province,
University of South China, Hunan 421001; ${ }^{2}$ Department of Pathology, The First Hospital of Changsha, Changsha,
Hunan 410005; ${ }^{3}$ Department of Pathology, The First People's Hospital of Youxian, Youxian, Hunan 412300, P.R. China

Received November 2, 2016; Accepted January 4, 2018

DOI: $10.3892 / \mathrm{ol} .2018 .8139$

\begin{abstract}
The present study examined the effect of diallyl disulfide (DADS) on the invasion and migration ability of HL-60 cells with a high expression of parkinsonism associated deglycase (DJ-1) in the nucleus (HHDN), and its molecular mechanism. A western blot assay was used to measure the effects of DADS and an Src inhibitor on the expression of DJ-1 and the Src signal pathway in HHDN. The effects of DADS and Src inhibitors on the invasion and migration ability of HHDN was detected using Transwell migration and invasion chamber experiments. The experiments were divided into three groups: A control group (HL-60 cells), an empty vector group and a high expression group (HHDN cells). Western blot assays revealed that the expression of DJ-1 in HHDN was inhibited in a time-dependent manner following treatment with DADS for 24, 48 and $72 \mathrm{~h}$. Following DADS treatment, the expression of phosphorylated Src (p-Src) and phosphorylated Fak (p-Fak) were significantly decreased in all groups compared with the untreated groups, however the expression level of Src, Fak and integrin did not change significantly. Western blot analysis results revealed that following treatment with DADS and Src inhibitor, the expression levels of p-Src and p-Fak significantly decreased in all three groups compared with untreated groups, whereas the expression levels of Src, Fak and integrin did not change significantly. The expression of DJ-1 in HHND was inhibited in time-dependent manner following treatment
\end{abstract}

Correspondence to: Professor Hui Tan, Cancer Research Institute, Key Laboratory of Tumor Cellular and Molecular Pathology, College of Hunan Province, University of South China, 28 West Changsheng Road, Hengyang, Hunan 421001, P.R. China

E-mail: 1047550723@qq.com

*Contributed equally

Key words: leukemia, diallyl disulfide, Src signaling pathway, parkinsonism associated deglycase, migration, invasion, Src with DADS and Src inhibitor for 24, 48 and $72 \mathrm{~h}$. Transwell migration and invasion assay results revealed that DADS and Src inhibitors may suppress migration and invasion in leukemic cells, and a combination of the two treatments may result in more efficient suppression. DADS may downregulate DJ-1-mediated invasion and migration in leukemic cells through suppressing the Src-Fak-Integrin signaling pathway, and the Src inhibitor may enhance the antitumor effect of DADS.

\section{Introduction}

Diallyl disulfide (DADS) is a major sulfuric compound of garlic, and exerts anti-inflammatory, immune-modulatory, and enhanced sympathetic activity effects. In the past few years, an increasing number of studies have indicated that DADS has antitumor activity in numerous types of tumors, including in neuroblastoma, breast cancer, colon cancer, lung cancer and stomach cancer (1-8). The proteomic analysis of 18 differing types of protein in HL-60 cells treated with DADS confirmed that parkinsonism associated deglycase (DJ-1) protein expression was significantly downregulated (9). DJ-1 protein, a $20 \mathrm{kDa}$ size protein, belongs to the Thi/PfpI protein superfamily and is expressed in lung, prostate and breast cancer that appears in the serum of patients meaning it may be used as a biomarker for breast cancer and melanoma (10). The carcinogenicity of DJ-1 is attributed to a number of factors. Firstly, the cancer may survive the antioxidant effect of the DJ-1 protein; and secondly, DJ-1 has the additional ability to resist apoptosis by the chelation of tumor protein $\mathrm{p} 53$, thus reducing the expression of BCL2 associated X apoptosis regulator and preventing caspase activation to inhibit target cell death, or by adjusting phosphatase and tensin homologue (PTEN) activity (11). DJ-1 protein is a particularly attractive target for cancer treatment as it is associated with proliferation, invasion, migration, chemotherapeutic resistance and apoptosis (12). In the human laryngeal carcinoma cell line snu-46, the enhanced expression of the DJ-1 gene resulted in invasion and migration capability enhancement (13), which has also been observed in nasopharyngeal carcinoma (14). 
The extensive local invasion and early systemic spread, and DJ-1 has been identified to regulate Src phosphorylation in the extracellular signaling pathway to promote cell migration, and invasion (15). The Src signaling pathway is associated with tumor invasion and migration, and an experimental study on the transplantation of a pancreatic tumor model indicated that the migration and invasion of pancreatic cancer cells was associated with the Src signaling pathway (16). Human non-small cell lung cancer cell line A549 may inhibit Src signaling pathways in order to weaken the cell invasion and migration (17). The activation of the Src signaling pathway was revealed to regulate the migration of cells in breast cancer tissue (18). In the present study, HL-60 cells with a high expression of DJ-1 in the nucleus (HHDN) were used to analyze the anti-invasion and anti-migration effects resulting from DADS treatment, and its mechanism. Western blot analysis, Transwell migration and invasion chamber assays were used to examine the mechanism of how DADS impacts the invasion, and migration ability in HHDN. Thus, providing novel prospects for the intervention and treatment of leukemia, and a theoretical basis for the optimization of DADS treatment for its antitumor effects.

\section{Materials and methods}

Cell culture and treatment. HL-60 cells, obtained from the Cancer Research Institute, Xiangya Medical College, Central South University of China, were cultured in RPMI-1640 medium (Hyclone; GE Healthcare Life Sciences, Logan, UT, USA) with $10 \%$ fetal calf serum (Gibco; Thermo Fisher Scientific, Inc., Waltham, MA, USA) at $37^{\circ} \mathrm{C}$ in a $5 \% \mathrm{CO}_{2}$ incubator. Cell culture was replaced with fresh medium every 2-3 days. The Cancer Research Institute of Central South University of China had previous successfully established stable HHDN, as well as an empty vector cell line of HL-60.

Reagents. DADS (purity $80 \%$, with the remaining $20 \%$ composed of diallyl trisulfide and diallyl sulfide), which was purchased from Honeywell Fluka ${ }^{\mathrm{TM}}$ (Thermo Fisher Scientific, Inc.), was dissolved in Tween-80 at a concentration of $8 \mathrm{mg} / \mathrm{ml}$ and stored at $-20^{\circ} \mathrm{C}$. DJ-1 monoclonal antibodies were purchased from Upstate Biotechnology, Inc., (Lake Placid, NY, USA; cat no. 05-828; 1:2,000 dilution). Fak and Src monoclonal antibodies were purchased from Abgent, Inc. (San Diego, CA, USA; cat no. A01386a; 1:1,000 dilution and cat no. AM7718a; 1:500 dilution, respectively). Phosphorylated Src (p-Src) was purchased from Cell Signaling Technology, Inc. (Danvers, MA, USA; cat. no. 2101; 1:1,000 dilution) and phosphorylated Fak (p-Fak) was purchased from Abgent, Inc. (cat no. AJ1285e; 1:1,000 dilution). $\beta$-actin monoclonal antibodies were purchased from Abgent, Inc. (cat. no. AM1021B-ev; 1:2,000 dilution).

Determination of cell viability. Cells were plated at a density of $1 \times 10^{4}$ cells/well in 96-well plates, and the cell viability was determined using a conventional MTT reduction assay according to the manufacturer's protocol. MTT assays rely primarily on the mitochondrial metabolic capacity of viable cells and reflect the intracellular redox state. Cells were treated with $0.00,1.25,2.50,5.00,10.00$ or $20.00 \mathrm{mg} / \mathrm{l}$ of $\mathrm{Src}$ inhibitor for $48 \mathrm{~h}$ at $37^{\circ} \mathrm{C}$. The medium was removed and
$100 \mu 1$ of DMSO was added to each well to dissolve the formed formazan dye crystals for $15 \mathrm{~min}$, subsequently the absorbance at $570 \mathrm{~nm}$ was measured using a microplate reader (Molecular Devices, LLC, Sunnyvale, CA, USA). Results were expressed as the percentage of the MTT reduction, assuming that the absorbance of the control was $100 \%$.

Western blot analysis. Cultures of HL-60 cells in the logarithmic growth phase at a density of $2 \times 10^{5}$ cells $/ \mathrm{ml}$ were harvested, washed with ice-cold PBS, and suspended in $0.5 \mathrm{ml}$ lysis buffer (10 mmol/l Tris- $\mathrm{HCl} \mathrm{pH} 7.6,100 \mathrm{mmol} / \mathrm{l} \mathrm{NaCl}$, $1.0 \mathrm{mmol} / 1$ ethylenediaminetetraacetic acid and $100 \mathrm{mg} / \mathrm{l}$ phenylmethylsulfonyl fluoride) containing protease inhibitor aprotinin $(1 \mathrm{mg} / \mathrm{l})$. Lysates were centrifuged at 8,000 x $\mathrm{g}$ for $10 \mathrm{~min}$ at $37^{\circ} \mathrm{C}$, and the protein concentrations in extracts were quantified using a bicinchoninic acid protein quantified kit according to the manufacturer's protocol. (Pierce; Thermo Fisher Scientific, Inc.). Total protein (20-25 $\mu \mathrm{g})$ was separated using $12 \%$ sodium dodecyl sulfate polyacrylamide gel electrophoresis and transferred to a polyvinylidene fluoride membrane. The membrane was blocked using 5\% nonfat milk in Tris-buffered saline (TBS) containing $0.1 \%$ Tween-20 for $2 \mathrm{~h}$ at room temperature and incubated for $2 \mathrm{~h}$ at room temperature with a 1:1,000 dilution of DJ-1 monoclonal antibodies. The antibody treated membrane was washed 3 times for $5 \mathrm{~min}$ in TBS containing $0.1 \%$ Tween-20 and then incubated with a 1:1,000 dilution of horseradish peroxidase (HRP)-conjugated secondary antibody (Sheep anti-rabbit immunoglobulin-HRP; cat no. KGAA35; 1:1,000 dilution; Nanjing KeyGen Biotech Co., Ltd., Nanjing, China) for $1 \mathrm{~h}$ at room temperature. The membrane was washed again 3 times for $10 \mathrm{~min}$ with TBS containing $0.1 \%$ Tween and developed by an enhanced Chemiluminescence Plus kit according to the manufacturer's protocol (cat no. CW0049M; Beijing ComWin Biotech Co., Ltd., Beijing, China). Experimental data were analyzed using GraphPad Prism 5 (GraphPad Software, Inc., La Jolla, CA, USA). Where indicated, the blots were stripped and reprobed with antibodies directed against $\beta$-actin (Sigma-Aldrich; Merck KGaA, Darmstadt, Germany).

Transwell cell migration assay. Logarithmic growth phase cells were collected and centrifuged at $200 \mathrm{x}$ g for $5 \mathrm{~min}$. Subsequently, the supernatant was discarded and serum-free medium (RPMI-1640 medium; Hyclone; GE Healthcare Life Sciences) was added to form the cell suspension, adjusting the cell concentration to $2 \times 10^{5}$ cells $/ \mathrm{ml}$. A total of $500 \mu \mathrm{l}$ culture medium containing a 0.1 volume fraction of fetal bovine serum was added to 24-well plates, which were placed in the Transwell chamber, and $200 \mu \mathrm{l}$ cell suspension was added and incubated at $37^{\circ} \mathrm{C}$ in a volume fraction of $0.05 \mathrm{CO}_{2}$ for $24 \mathrm{~h}$. Seeded in 96-well plates, each well had $20 \mu \mathrm{l}$ MTT solution added and incubation continued for $4 \mathrm{~h}$. Centrifugation was performed at $400 \mathrm{x} \mathrm{g}$ for $5 \mathrm{~min}$ at $37^{\circ} \mathrm{C}$, and DMSO $(150 \mu \mathrm{l})$ was added to each well, agitated for $20 \mathrm{~min}$ in a flat shaker, Subsequently, the absorbance of each well was measured using ELISA at a $450 \mathrm{~nm}$ wavelength (cat no. ab100578; Abcam, Cambridge, UK) according to the manufacturer's protocol.

Transwell cell invasion assay. Solid Matrigel was placed in the refrigerator overnight at $4^{\circ} \mathrm{C}$ and then dissolved into liquid. 

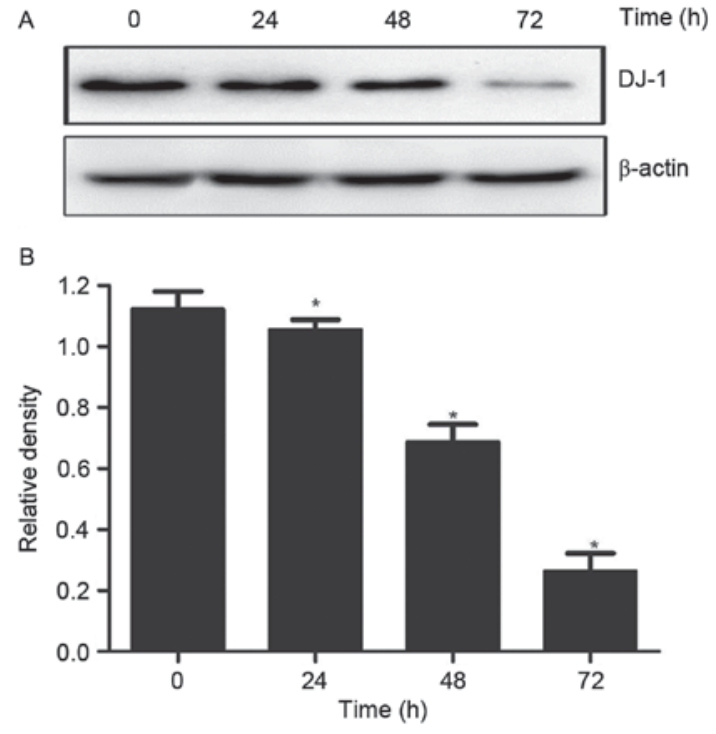

Figure 1. Analysis of the expression levels of DJ-1 protein in HL-60 cells treated with DADS for 0, 24, 48 and $72 \mathrm{~h}$. (A) A representative western blot analysis presenting DJ-1 expression in HL-60 cells treated with DADS for differing lengths of time. (B) Quantification of the DJ-1 expression levels in western blot analyses. ${ }^{*} \mathrm{P}<0.05$ vs. the control. DJ-1, parkinsonism associated deglycase; DADS, diallyl disulfide.

A 24-well culture plate was placed into the Transwell chamber, and diluted Matrigel (50 $\mu \mathrm{l})$ was added to each chamber under $15^{\circ} \mathrm{C}$. Subsequently, it was placed into a cell incubator overnight Logarithmic growth phase cells were collected, the serum removed and RPMI-1640 medium (Hyclone; GE Healthcare, Chicago, IL, USA) prepared as the cell suspension, which adjusted the cell concentration to $2 \times 10^{5}$ cells $/ \mathrm{ml}$. In the 24 -well plates placed in the lower chamber, a 0.1 volume fraction of fetal bovine serum medium $(500 \mu \mathrm{l})$ was added, in addition to $200 \mu \mathrm{l}$ cell suspension and cultured for $24 \mathrm{~h}$. The chamber was immersed in $4 \%$ paraformaldehyde for $30 \mathrm{~min}$ at $37^{\circ} \mathrm{C}$ and rinsed two times with PBS. Then, when completely dry, staining was performed using a pre-diluted 1:9 Giemsa dye liquor at room temperature for 20-30 min. Subsequently it was rinsed with deionized water several times, and several sections were selected at random to be visualized under the light microscope (magnification, x20). The number of cells were then calculated.

Statistical analysis. Data are expressed as the mean \pm the standard deviation. The significance of inter-group differences was evaluated using a one-way analysis of variance with Scheffe's test used for post hoc comparisons. Transwell and western blot data were analyzed using SPSS statistical software (version 18.0; SPSS, Chicago, IL, USA). P<0.05 was considered to indicate a statistically significant difference.

\section{Results}

DADS treatment affects the expression levels of DJ-1 protein in $H L-60$ cells. In order to test the effect of DADS on the expression levels of DJ-1 protein in HL-60 cells, the DJ-1 protein expression levels were measured following DADS treatment in HL-60. Western blot analysis results indicated that the expression levels of DJ-1 protein in HHDN cells treated with DADS

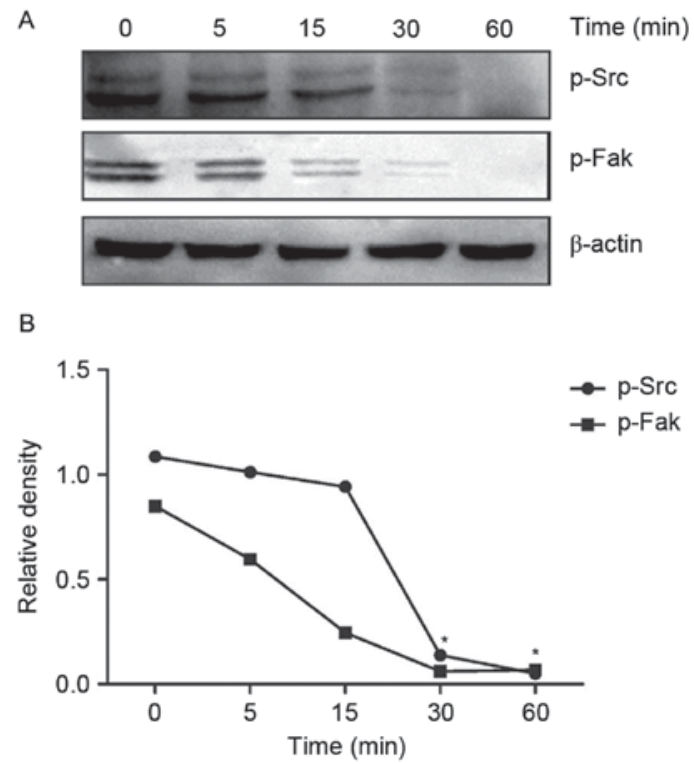

Figure 2. The expression of p-Src and p-Fak in the HL-60 cells with a high expression of DJ-1 in the nucleus induced by diallyl disulfide for $0,5,15,30$ or $60 \mathrm{~min}$. (A) A representative western blot analysis presenting the expression of $\mathrm{p}$-Src and p-Fak. (B) Comparisons between the expression levels of p-Src and p-Fak. "P<0.05 vs. the control. p-Src, phosphorylated Src protein; p-Fak, phosphorylated Fak protein; DJ-1, parkinsonism associated deglycase.

for 24,48 and $72 \mathrm{~h}$ was significantly reduced, demonstrating a time-dependent decrease $(\mathrm{P}<0.05$; Fig. 1).

DADS affects the Src signaling pathway in HHDN cells. In order to test the effect of DADS treatment on the Src signaling pathway, the protein expression levels of DADS-treated HHDN cells at time intervals of $0,5,15,30$ and 60 min was examined. Compared with untreated cells, after HL-60 cells were treated with DADS for $30 \mathrm{~min}$, the expression of $\mathrm{p}-\mathrm{Src}$ and $\mathrm{p}$-Fak was gradually inhibited (Fig. 2A). It also demonstrated a direct decline in protein expression levels with an increase in DADS treatment time (Fig. 2B). The protein expression levels of Src and Fak almost reached zero after 60 min of treatment, when the expression of Src and Fak was absolutely inhibited.

After 30 min of treatment with DADS, in a control group, empty vector group and high expression group, the expression levels of p-Frk and p-Src compared with the untreated groups was significantly reduced, with a statistically significant difference $(\mathrm{P}<0.05$; Fig. 3). No significant difference was identified in the high expression group compared with the control group and empty vector group ( $\mathrm{P}>0.05)$, indicating that DADS may inhibit the Src signaling pathway. Additionally, in the three groups of cells without DADS treatment, Src and Fak were highly expressed compared with treated cells. In leukemia cells, the Src signaling pathway is in an activated state.

Effect of DADS and Src inhibitor on the Src signaling pathway of HHDN cells. Following treatment with DADS and Src inhibitor, the expression levels of p-Src and p-Fak compared with the untreated group were significantly inhibited, and the difference was statistically significant $(\mathrm{P}<0.05$; Fig. 4). However, there was no significant difference between the high expression group and the control group and empty vector group $(\mathrm{P}>0.05)$. The results demonstrated that DADS and 
A
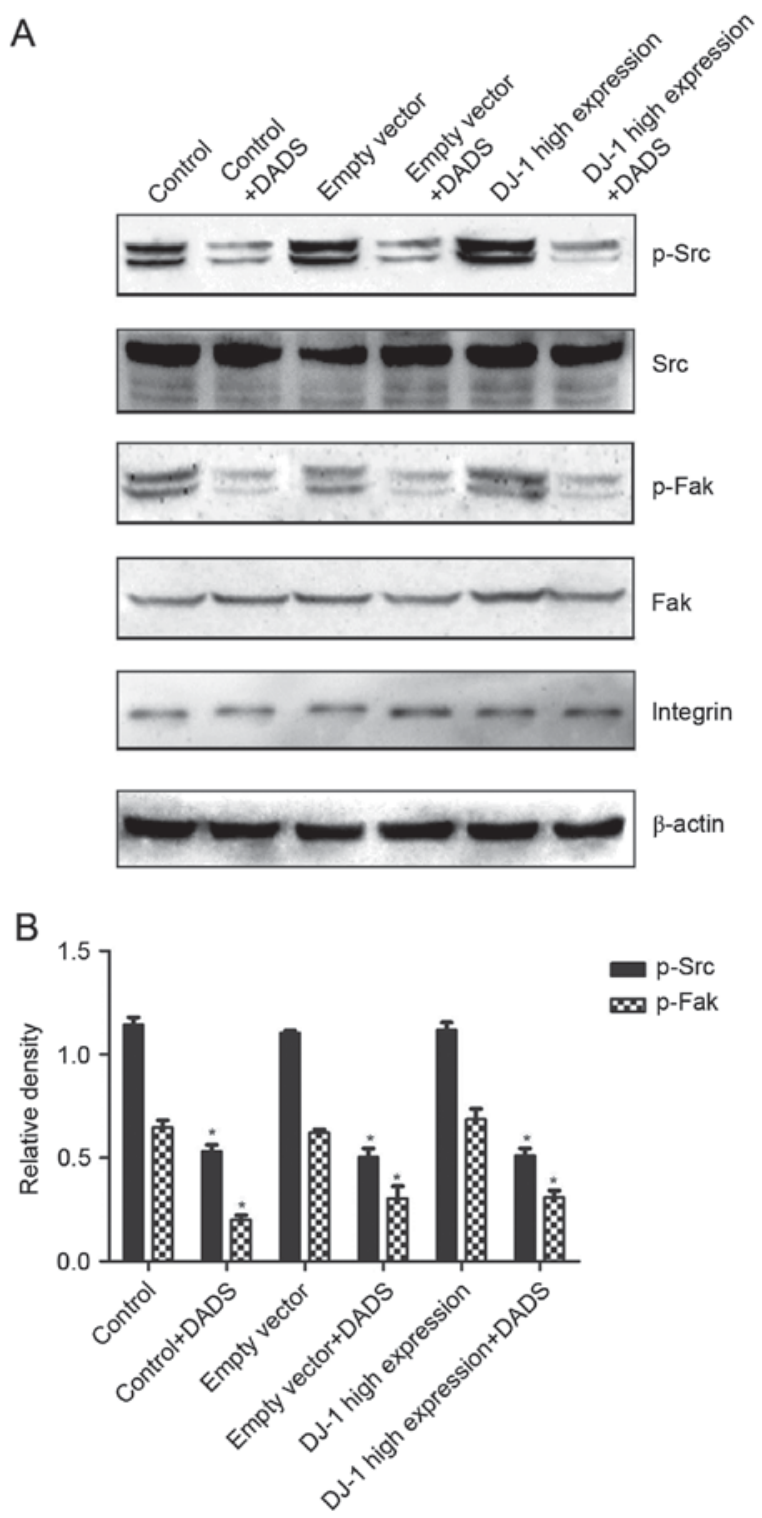

Figure 3. DADS affects the Src signaling pathway in a control group, empty vector group and high expression group. (A) Protein expression of p-Src, Src, P-Fak, Fak and integrin was examined using western blot analysis. (B) Quantified protein expression of $\mathrm{p}$-Src and $\mathrm{p}$-Fac across the three groups. ${ }^{*} \mathrm{P}<0.05$ vs. the control. DADS, diallyl disulfide; DJ-1, parkinsonism associated deglycase; p-Src, phosphorylated Src protein; p-Fak, phosphorylated Fak protein.

Src inhibitors may be combined to inhibit the Src signaling pathway.

Effect of DADS and Src inhibitor on the DJ-1 protein expression levels of HHDN cells. Compared with the untreated group, DJ-1 protein expression levels demonstrated a time-dependent decrease with DADS and Src inhibitor treated HHDN at 24,48 and $72 \mathrm{~h}$, with a statistically significant difference $(\mathrm{P}<0.05)$, indicating that the DJ-1 gene may be a potential therapeutic target (Fig. 5).

Effect of DADS and Src inhibitor treatment on the invasion and migration ability of HHDN cells. It was revealed that in the high expression cells of each group compared with the control group, the high expression group presented a significantly
A

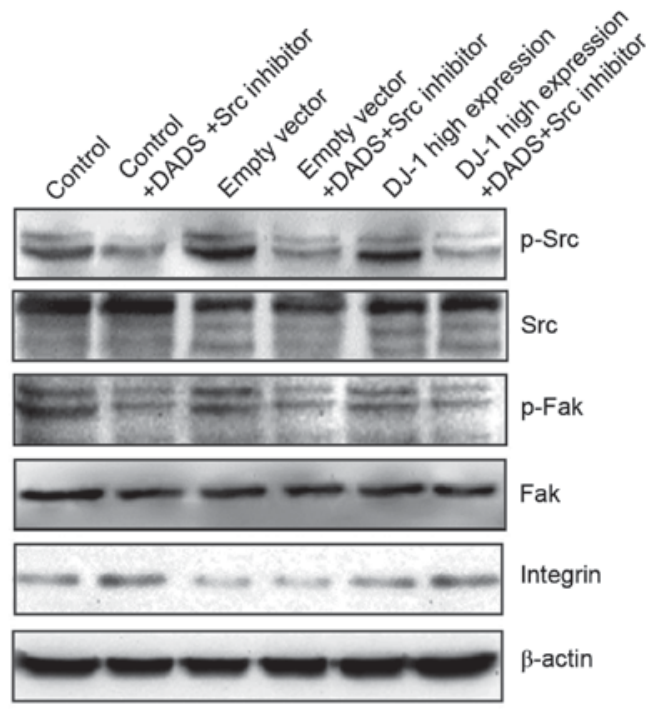

B

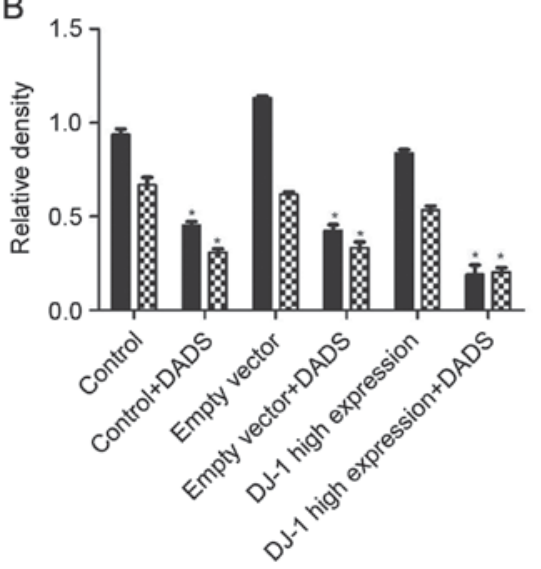

Figure 4. DADS and Src inhibitor inhibit the Src signaling pathway in the control group, the empty vector group and the high expression group. Protein expression of p-Src, Src, P-Fak, Fak and integrin was examined by (A) western blot analysis and (B) quantitative analysis. ${ }^{*} \mathrm{P}<0.05$ vs. the control. DADS, diallyl disulfide; p-Src, phosphorylated Src protein; p-Fak, phosphorylated Fak protein; DJ-1, parkinsonism associated deglycase.

higher migration rate $(\mathrm{P}<0.05)$, which demonstrated a positive association between the high expression of DJ-1 and the migration of HL-60 cells (Table I, Fig. 6). Following treatment with DADS for $24 \mathrm{~h}$, the cell migration rate of the two groups decreased significantly compared with the control $(\mathrm{P}<0.05)$, while the groups treated with Src inhibitor for $24 \mathrm{~h}$ presented no significant difference compared with the DADS groups $(\mathrm{P}>0.05)$. Groups treated with combined DADS and Src inhibitor treatment presented a significantly lower cell migration rate compared with groups treated with either DADS or Src inhibitor alone $(\mathrm{P}<0.05)$. All results indicate that DADS and Src inhibitor treatments individually inhibit leukemia cell migration, and demonstrate synergistic effects on the inhibition of leukemia cell migration.

The invasion cell numbers through the matrigel in the high expression groups were greater compared with the numbers in the control groups, which indicated a positive association between the high expression of DJ-1 and the invasion ability of HL-60 cells. Following treatment with DADS for $24 \mathrm{~h}$, the number of cells counted that had invaded through the matrigel in the DADS treated group had decreased significantly 
Table I. Effect of DADS and Src inhibitor treatments on the migration ability of HHDN cells.

\begin{tabular}{lcccc}
\hline Group & No treatment group & DADS-treated group & Src inhibitor-treated group & Combined treatment group \\
\hline HHDN & $1.514 \pm 0.04^{\mathrm{a}}$ & $1.117 \pm 0.03^{\mathrm{b}, \mathrm{a}}$ & $1.163 \pm 0.02^{\mathrm{b}, \mathrm{a}}$ & $0.929 \pm 0.04^{\mathrm{c}, \mathrm{a}}$ \\
HL-60 & $1.136 \pm 0.05$ & $0.739 \pm 0.04^{\mathrm{b}}$ & $0.775 \pm 0.02^{\mathrm{b}}$ & $0.516 \pm 0.03^{\mathrm{c}}$ \\
\hline
\end{tabular}

${ }^{\mathrm{a}} \mathrm{P}<0.05$ vs. the control group; ${ }^{\mathrm{b}} \mathrm{P}<0.05$ vs. the untreated group; ${ }^{\mathrm{c}} \mathrm{P}<0.05$ vs. the DADS group and Src inhibitor group. DADS, diallyl disulfide; HHND, HL-60 cells with a high expression of DJ-1 in the nucleus; DJ-1, parkinsonism associated deglycase.

A
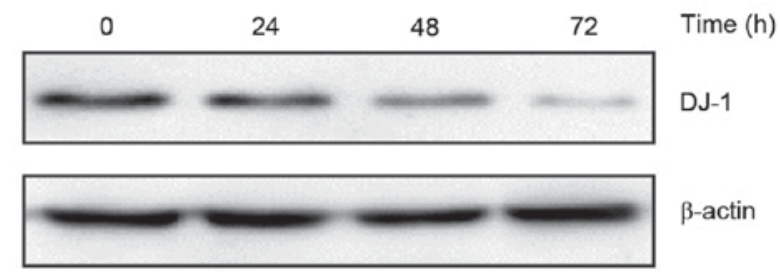

B

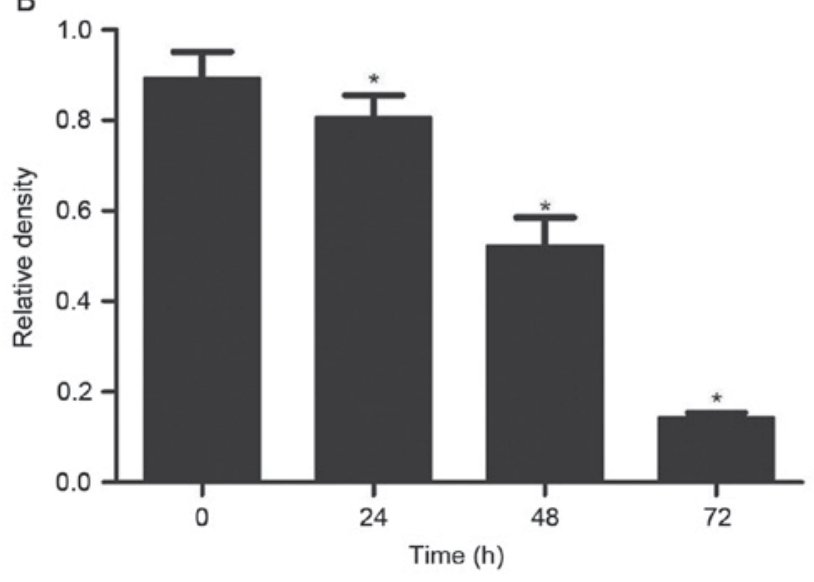

Figure 5. Western blot analysis of the effect of diallyl disulfide and Src inhibitor on the DJ-1 protein expression levels in HL-60 cells with a high expression of DJ-1 in the nucleus at 0,24, 48 and $72 \mathrm{~h}$. (A) A representative western blot analysis for DJ-1. (B) Quantification of DJ-1 expression levels in western blot analyses. " $\mathrm{P}<0.05$ vs. the control. DJ-1, parkinsonism associated deglycase.

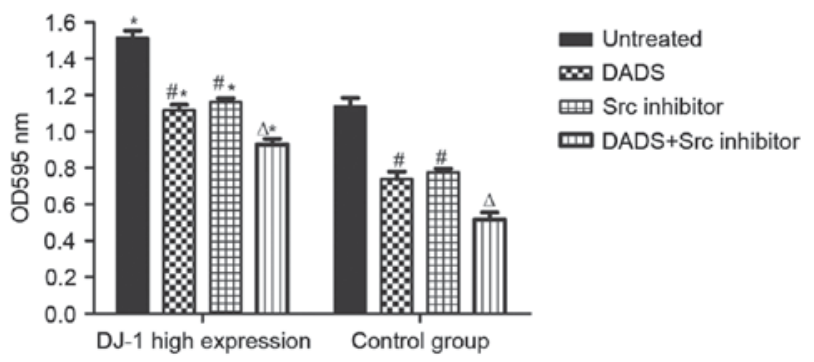

Figure 6. Effect of DADS and Src inhibitor treatments on the migration ability of HL-60 cells with a high expression of DJ- 1 in the nucleus. " $\mathrm{P}<0.05$ vs. the control group; ${ }^{*} \mathrm{P}<0.05$ vs. untreated; ${ }^{\circ} \mathrm{P}<0.05$ vs. the DADS group and Src inhibitor group. DADS, diallyl disulfide; DJ-1, parkinsonism associated deglycase; OD, optical density.

compared to the untreated group, however no difference was apparent compared with the groups treated with Src inhibitor treatment for $24 \mathrm{~h}(\mathrm{P}>0.05)$. Furthermore, the groups treated with combined DADS and Src inhibitor demonstrated a lower cell count compared with the groups treated with either DADS or Src inhibitor alone $(\mathrm{P}<0.05$; Table II and Fig. 7). The results revealed that DADS and Src inhibitor treatments individually inhibit leukemia cell invasion, and demonstrated synergistic effects on the inhibition of leukemia cell invasion.

\section{Discussion}

DADS, an organic sulfuric compound present in garlic, is a promising anticancer candidate that inhibits a variety of types of tumor (19-23). In tumor cell differentiation, cell cycle regulation and apoptosis, it may inhibit the expression of certain oncogenes (24). In addition, one study has demonstrated that DADS exhibits stronger antitumor effects compared with cisplatin on certain tumors, and presents fewer side effects (25).

In clinical practice, $>90 \%$ of patients with cancer succumb due to tumor invasion and metastasis (26). A previous study has demonstrated that DADS significantly inhibited the proliferation of HL-60 cells cultured in vitro in a dose-responsive manner. Moderate doses ( $>1.25 \mathrm{mg} / \mathrm{l})$ may induce apoptosis in HL-60 cells, whereas low-dose DADS $(<1.25 \mathrm{mg} / \mathrm{l})$ induced the differentiation of HL-60 cells (27). It was preliminarily identified that DADS is able to induce the expression of 18 differing types of protein in human leukemia HL-60 cells, of which DJ-1 protein may be downregulated, which belongs to a cancer-causing protein family associated with oncogenesis and development (28).

DJ-1 is an oncogenic protein that regulates the interaction between proteins and RNA, and previous studies have revealed that DJ-1 is highly expressed in lung, esophageal, pancreatic, liver, breast and laryngeal cancer, as well as other malignant tumors (29-32). Upregulated expression of the DJ-1 gene may promote oncogenesis, and inhibit the reduce proliferation of chemotherapeutic drugs against cancer cells, which is associated with chemotherapeutic resistance. These studies suggest that the cancer-promoting gene DJ-1 may be used to diagnose and predict prognosis in patients with cancer, and has potential value in clinical practice (33).

DJ-1, expressed in the cytoplasm, nucleus and mitochondria, is a regulatory molecule of gene transcription. In the $\mathrm{S}$ phase, it is transferred from the cytoplasm to the nucleus, and DJ-1 expressed in different subcellular locations regulates different physiological and pathological features. If expression is localized to the mitochondria, then it is involved in oxidative stress process $(33,34)$, whilst nuclear localized expression inhibits apoptosis $(35,36)$. DJ-1 highly expressed in the nucleus promotes HL-60 cell proliferation and migration, and enhances invasion capability, but an interfering DJ-1 gene is able to enhance proliferation inhibition against DADS and induce the differentiation of HL-60 cells (37). 
Table II. Effect of DADS and Src inhibitor treatments on the invasion ability of HHDN.

\begin{tabular}{lcccc}
\hline Group & No treatment group & DADS-treated group & Src inhibitor-treated group & Combined treatment group \\
\hline HHDN & $221.7 \pm 5.897^{\mathrm{a}}$ & $155.3 \pm 6.173^{\mathrm{a}, \mathrm{b}}$ & $162.7 \pm 3.844^{\mathrm{a}, \mathrm{b}}$ & $89.67 \pm 4.910^{\mathrm{a}, \mathrm{c}}$ \\
HL-60 cells & $175.3 \pm 6.642$ & $117.3 \pm 5.783^{\mathrm{b}}$ & $122.3 \pm 3.930^{\mathrm{b}}$ & $73.67 \pm 4.410^{\mathrm{c}}$ \\
\hline
\end{tabular}

${ }^{\text {a }}<0.05$ vs. the control group; ${ }^{\mathrm{b}} \mathrm{P}<0.05$ vs. the untreated group; ${ }^{\mathrm{c}} \mathrm{P}<0.05$ vs. the DADS group and Src inhibitor group. DADS, diallyl disulfide; HHDN, HL-60 cells with a high expression of DJ-1 in the nucleus; DJ-1, parkinsonism associated deglycase.
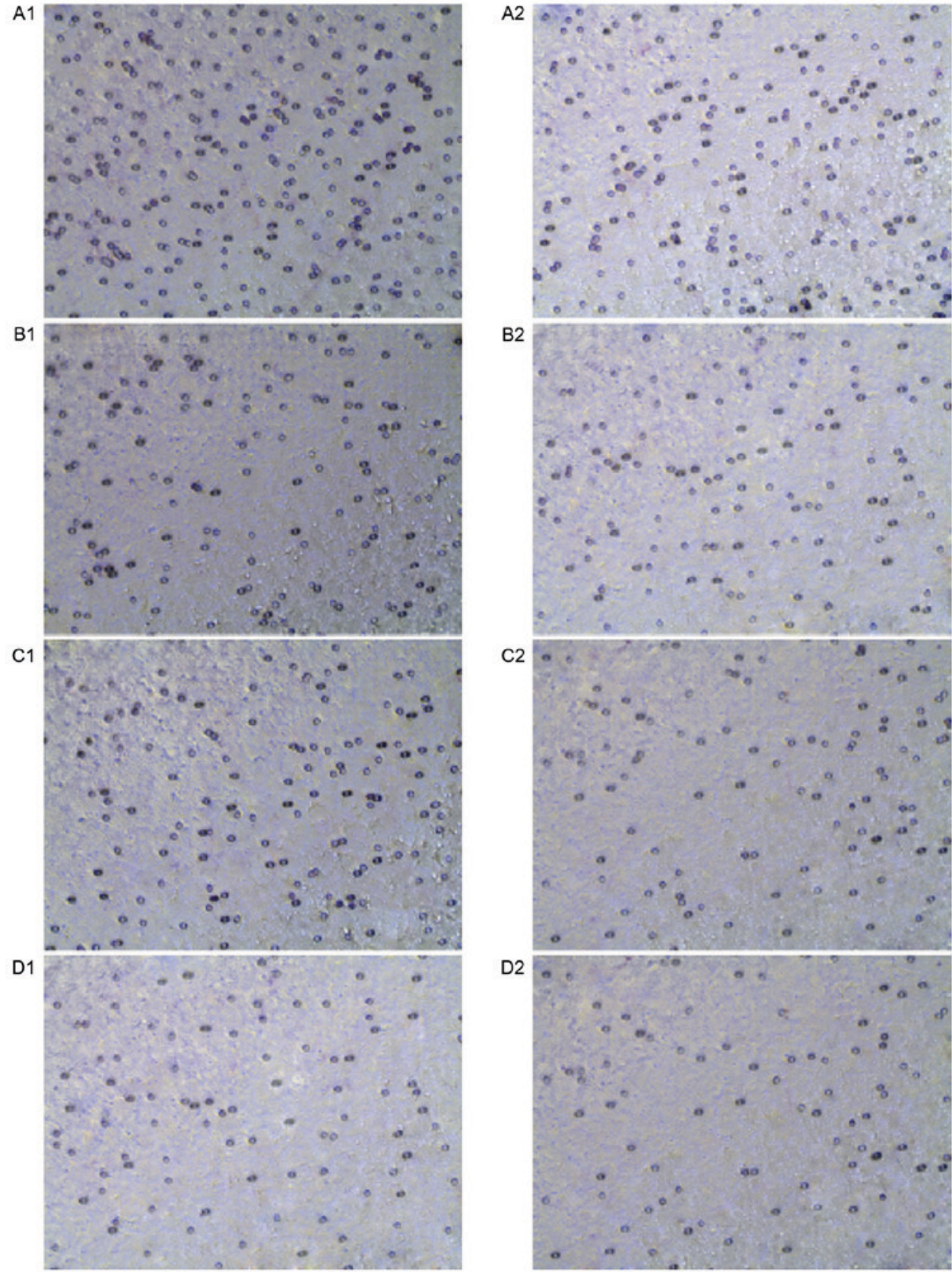

B2

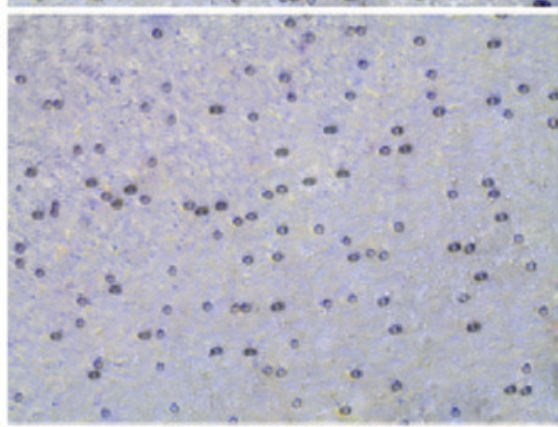

$\mathrm{C} 2$

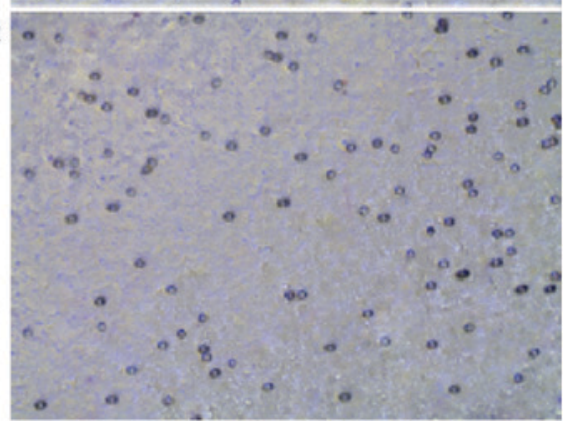

D2

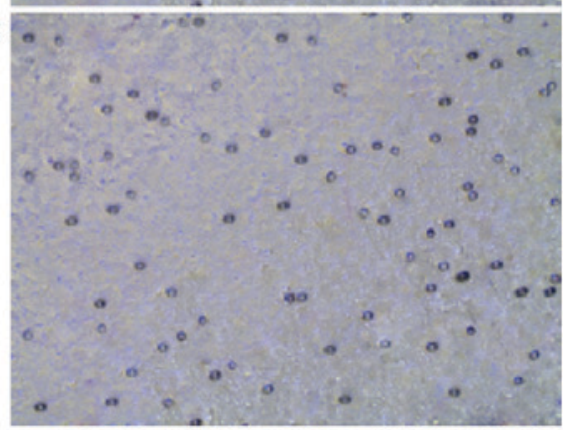

Figure 7. Effect of DADS and Src inhibitor on the invasion of HHDN (magnification, $x 20$ ). (A) The invasion ability of untreated (1) HHDN and (2) HL-60 cells. (B) The invasion ability of DADS-treated (1) HHDN and (2) HL-60 cells. (C) The invasion ability of Src inhibitor-treated (1) HHDN and (2) HL-60 cells. (D) The invasion ability of combined DADS and Src inhibitor-treated (1) HHDN and (2) HL-60 cells. P<0.05 vs. untreated. DADS, diallyl disulfide; HHDN, HL-60 cells with a high expression of DJ-1 in the nucleus; DJ-1, parkinsonism associated deglycase.

HHDN are a highly invasive cell line, as the migration and invasion ability of tumor cells appears to be associated with highly-expressed DJ-1; however, its mechanism remains unclear $(14,30,38-40)$. In the present study, western blot 
analysis was used to examine how DADS affects the expression of the DJ-1 protein in HHND cells, and the DJ-1 protein expression levels revealed a time-dependent decrease with DADS-treatment. Thus, it was posited that DADS may downregulate the expression of DJ-1, and inhibit the migration and invasion ability of HHND cells. However, the specific mechanism remains unknown and is yet to be confirmed.

DJ-1 promotes tumor cell division, proliferation, migration and invasion, and is likely to be involved in several coordinated intracellular molecular pathways. Li et al (41) reported that the DJ-1 protein is one of the major negative regulator proteins of the PTEN tumor suppressor gene. DJ-1 protein promotes tumor cell proliferation and growth by inhibiting PTEN activity, and stimulating the phosphoinositide 3-kinase/protein kinase B signaling pathway (42). DJ-1 promotes nuclear translocation of nuclear factor- $\kappa \beta$, regulates cell differentiation and inhibits apoptosis (43). DJ-1 regulates the transcription factor nuclear factor erythroid 2-related factor 2 signaling pathway and promotes cytoprotective gene expression (44). It is also a target of regulation of Src and extracellular signal-regulated kinase signaling pathways, promoting tumor cell proliferation, migration and invasion (45).

It was revealed that integrins are associated with tumor cell adhesion, migration and invasion in a transplanted tumor model of breast cancer in zebrafish, and mice $(46,47)$. The extracellular matrix-integrin signal transduction pathway is involved with the Src signaling pathway, where Fak is a key factor. Under the action of integrin, Fak phosphorylates and interacts with Src (48). An experimental study has confirmed that interfering PTEN may inhibit the phosphorylation of Fak so as to inhibit the proliferation, migration and invasion of liver cancer, and leukemia cell (42). Thus, it was hypothesized that DJ-1 and Src signaling pathways may be potentially associated in the invasion, and migration of leukemic cells (49). Scr promotes cell proliferation, adhesion, migration and invasion in tumorigenesis (50). Src activation is required for induction of integrin (51). In the present study, a western blot analysis was used to examine how DADS influences the Src signaling pathways in HHND cells, and further confirmed that DADS may inhibit the invasion of and migration of HHND cells through negative regulation of the Src signaling pathway. The results revealed that DADS may inhibit the Src signaling pathway.

Src kinases in targeted therapy is an important topic (52). Inhibiting Src activity may inhibit the proliferation of a variety of types of tumor, including the invasive migratory effect $(53,54)$. In the present study, it was revealed that Src treatment may inhibit the migration and invasion ability of leukemia cells, whereas the combination of DADS and Src treatments demonstrated more significant inhibitory effects. Therefore, it may be considered that antagonizing the Src signaling pathway inhibits the invasion and migration ability of leukemia cells.

In conclusion, DADS suppresses the invasion and migration of HHND cells by antagonizing the Src signaling pathway and downregulating its expression. It was demonstrated that DJ-1 may be a potential target for gene therapy, and may improve the DADS antitumor effect on leukemia. Finally, Src inhibitor combined with DADS treatment may be used as a type of therapy to achieve more improved antitumor effects, providing a more safe and effective drug for patients with leukemia.

\section{Acknowledgements}

Not applicable.

\section{Funding}

The present study was supported by the Construct Program of the Key Discipline in the Hunan Province of China [grant no. (2011)76], the National Natural Science Foundation of China (grant nos. 81100375; 81400117) and the Platform Open Innovation Fund Project for Hunan Province Universities (grant no. 1 1K057).

\section{Availability of data and materials}

The datasets generated and analyzed in the present study are included in this published article.

\section{Authors' contributions}

RL and YY conducted the majority of the experiments and analyzed data, and wrote the manuscript. JQ, QL, WW, JW and YT performed experiments. LY contributed reagents and performed experiments. HT designed the project and led the team to accomplish it. All authors reviewed the manuscript.

\section{Ethics and consent to participate}

Medical Ethical Committee of University of South China approved, and written informed consent was gained from all participants.

\section{Consent for publication}

The study participants provided consent for the data to be published.

\section{Competing interests}

The authors declare that they have no competing interests.

\section{References}

1. Pratheeshkumar P, Thejass P and Kutan G: Diallyl disulfide induces caspase-dependent apoptosis via mitochondria-mediated intrinsic pathway in B16F-10 melanoma cells by up-regulating p53, caspase-3 and down-regulating pro-inflammatory cytokines and nuclear factor- $\kappa \beta$-mediated $\mathrm{Bcl}-2$ activation. J Environ Pathol Toxicol Oncol 29: 113-125, 2010.

2. Altonsy MO, Habib TN and Andrews SC: Diallyl disulfide-induced apoptosis in a breast-cancer cell line (MCF-7) may be caused by inhibition of histone deacetylation. Nutr Cancer 64: 1251-1260, 2012

3. Tang H, Kong Y, Guo J, Tang Y, Xie X, Yang L, Su Q and Xie X: Diallyl disulfide suppresses proliferation and induces apoptosis in human gastric cancer through Wnt-1 signaling pathway by up-regulation of miR-200b and miR-22. Cancer Lett 340: 72-81, 2013.

4. Xiao X, Chen B, Liu X, Liu P, Zheng G, Ye F, Tang H and Xie X: Diallyl disulfide suppresses SRC/Ras/ERK signaling-mediated proliferation and metastasis in human breast cancer by upregulating miR-34a. PLoS One 9: e112720, 2014.

5. Truong D, Hindmarsh $\mathrm{W}$ and O'Brien PJ: The molecular mechanisms of diallyl disulfide and diallyl sulfide induced hepatocyte cytotoxicity. Chem Biol Interact 180: 79-88, 2009. 
6. Lee IC, Kim SH, Baek HS, Moon C, Kim SH, Kim YB, Yun WK, Kim HC and Kim JC: Protective effects of diallyl disulfide on carbon tetrachloride-induced hepatotoxicity through activation of Nrf2. Environ Toxicol 30: 538-548, 2015.

7. Yin X,Zhang J,LiX,Liu D,Feng C,Liang R,Zhuang K, CaiC, XueX, Jing F, et al: DADS suppresses human esophageal xenograft tumors through RAF/MEK/ERK and mitochondria-dependent pathways. Int J Mol Sci 15: 12422-12441, 2014.

8. Tsubura A, Lai YC, Kuwata M, Uehara N and Yoshizawa K: Anticancer effects of garlic and garlic-derived compounds for breast cancer control. Anticancer Agents Med Chem 11: 249-253, 2011.

9. HE Jie WY and Huang WG: Analysis of protein expression of cell differentiation induced by HL-60 cells by two dimensional gel electrophoresis. J Nan Uni (Med Edi):32: 143-6, 2004.

10. Chien CH, Lee MJ, Liou HC, Liou HH and Fu WM: Local immunosuppressive microenvironment enhances migration of melanoma cells to lungs in DJ-1 knockout mice. PLoS One 10: e0115827, 2015.

11. Fan J, Ren H, Jia N, Fei E, Zhou T, Jiang P, Wu M and Wang G: DJ-1 decreases Bax expression through repressing p53 transcriptional activity. J Biol Chem 283: 4022-4030, 2008.

12. Pei XJ, Wu TT, Li B, Tian XY, Li Z and Yang QX: Increased expression of macrophage migration inhibitory factor and DJ-1 contribute to cell invasion and metastasis of nasopharyngeal carcinoma. Int J Med Sci 11: 106-115, 2013.

13. Wang B, Qin H, Wang Y, Chen W, Luo J, Zhu X, Wen W and Lei W: Effect of DJ-1 overexpression on the proliferation, apoptosis, invasion and migration of laryngeal squamous cell carcinoma SNU-46 cells through PI3K/AKT/mTOR. Oncol Rep 32: 1108-1116, 2014.

14. Devine MJ, Plun-Favreau H and Wood NW: Parkinson's disease and cancer: Two wars, one front. Nat Rev Cancer 11: 812-823, 2011

15. He X, Zheng Z, Li J, Ben Q, Liu J, Zhang J, Ji J, Yu B, Chen X, $\mathrm{Su} \mathrm{L}$, et al: DJ-1 promotes invasion and metastasis of pancreatic cancer cells by activating SRC/ERK/uPA. Carcinogenesis 33: $555-562,2012$.

16. Che P, Yang Y, Han X, Hu M, Sellers JC, Londono-Joshi AI, Cai GQ, Buchsbaum DJ, Christein JD, Tang Q, et al: S100A4 promotes pancreatic cancer progression through a dual signaling pathway mediated by Src and focal adhesion kinase. Sci Rep 5 : 8453,2015

17. Ku MJ, Kim JH, Lee J, Cho JY, Chun T and Lee SY: Maclurin suppresses migration and invasion of human non-small-cel lung cancer cells via anti-oxidative activity and inhibition of the Src/FAK-ERK- $\beta$-catenin pathway. Mol Cell Biochem 402: 243-252, 2015.

18. Fang XQ, Liu XF, Yao L, Chen CQ, Lin JF, Gu ZD, Ni PH, Zheng XM and Fan QS: Focal adhesion kinase regulates the phosphorylation protein tyrosine phosphatase- $\alpha$ at Tyr789 in breast cancer cells. Mol Med Rep 11: 4303-4308, 2015.

19. Altonsy MO, Habib TN and Andrews SC: Diallyl disulfide-induced apoptosis in a breast-cancer cell line (MCF-7) may be caused by inhibition of histone deacetylation. Nutr Cancer 64 : 1251-1260, 2012

20. Kwon KB, Yoo SJ, Ryu DG, Yang JY, Rho HW, Kim JS, Park JW, Kim HR and Park BH: Induction of apoptosis by diallyl disulfide through activation of caspase-3 in human leukemia HL-60 cells. Biochem Pharmacol 63: 41-47, 2002.

21. Jakubíková J and Sedlák J: Garlic-derived organosulfides induce cytotoxicity, apoptosis, cell cycle arrest and oxidative stress in human colon carcinoma cell lines. Neoplasma 53 191-199, 2006

22. Wu XJ, Kassie F and Mersch-Sundermann V: The role of reactive oxygen species (ROS) production on diallyl disulfide (DADS) induced apoptosis and cell cycle arrest in human A549 lung carcinoma cells. Mutat Res 579: 115-124, 2005.

23. Nakagawa H, Tsuta K, Kiuchi K, Senzaki H, Tanaka K, Hioki K and Tsubura A: Growth inhibition effects of diallyl disulfide on human breast cancer cell lines. Carcinogenesis 22: 891-897, 2001.

24. Shin DY, Kim GY, Lee JH, Choi BT, Yoo YH and Choi YH: Apoptosis induction of human prostate carcinoma DU145 cells by diallyl disulfide via modulation of JNK and PI3K/AKT signaling pathways. Int J Mol Sci 13: 14158-14171, 2012.

25. Tsubura A, Lai YC, Kuwata M, Uehara N and Yoshizawa K: Anticancer effects of garlic and garlic-derived compounds for breast cancer control. Anticancer Agents Med Chem 11: 249-253, 2011.
26. Carpinteiro A, Becker KA, Japtok L, Hessler G, Keitsch S, Požgajovà M, Schmid KW, Adams C, Müller S, Kleuser B, et al: Regulation of hematogenous tumor metastasis by acid sphingomyelinase. EMBO Mol Med 7: 714-734, 2015

27. Wu MH TL, Li LP, Huang WG and Su Q: Effect of growth inhibition and differentiation of HL-60 cell induced by diallyl disulfide. Zhonghua Xue Ye Xue Za Zhi 25: 300-2, 2004.

28. He J SQ, Huang WG, Xie HL, Liang SP, Song Y and Xie JY: Proteomic initial Analysis of differentiation of human myeloid leukemia cells induced by diallyl disulfide. FEBS J 272 (Suppl 1): 440, 2005.

29. Zhang HY, Wang HQ, Liu HM, Guan Y and Du ZX: Regulation of tumor necrosis factor-related apoptosis-inducing ligand-induced apoptosis by DJ-1 in thyroid cancer cells. Endocr Relat Cancer 15: 535-544, 2008.

30. Wu F, Liang YQ and Huang ZM: The expression of DJ-1 gene in human hepatocellular carcinoma and its relationship with tumor invasion and metastasis. Zhonghua Gan Zang Bing Za Zhi 17: 203-206, 2009 (In Chinese).

31. Zhu XL, Wen WP, Lei WB, Chai LP, Hou WJ, Wen YH and Wang XR: DJ-1 expression in laryngeal squamous cell carcinoma and its relationship with tumor recurrence and metastasis Zhonghua Er Bi Yan Hou Tou Jing Wai Ke Za Zhi 45: 497-501, 2010 (In Chinese).

32. Wei W, Tang C, Zhan X, Yi H and Li C: Effect of DJ-1 siRNA on biological behavior of human lung squamous carcinoma SK-MES-1 cells. Zhong Nan Da Xue Xue Bao Yi Xue Ban 38: 7-13, 2013 (In Chinese).

33. Junn E, Jang WH, Zhao X, Jeong BS and Mouradian MM Mitochondrial localization of DJ-1 leads to enhanced neuroprotection. J Neurosci Res 87: 123-129, 2009.

34. Hao LY, Giasson BI and Bonini NM: DJ-1 is critical for mitochondrial function and rescues PINK1 loss of function. Proc Natl Acad Sci USA 107: 9747-9752, 2010.

35. Junn E, Taniguchi H, Jeong BS, Zhao X, Ichijo $H$ and Mouradian MM: Interaction of DJ-1 with Daxx inhibits apoptosis signal-regulating kinase 1 activity and cell death. Proc Natl Acad Sci USA 102: 9691-9696, 2005.

36. Hwang S, Song S, Hong YK, Choi G, Suh YS, Han SY, Lee M, Park SH, Lee JH, Lee S, et al: Drosophila DJ-1 decreases neural sensitivity to stress by negatively regulating Daxx-like protein through dFOXO. PLoS Genet 9: e1003412,2013.

37. JuanWang, yY Jing, Qing Yuxian, Tang Qingye, Li Qi and Su Hui Tan: DADS inhibits proliferation and differentiation of human leukemia HL60 cells by down regulated. Chinese Pharmacological Bulletin: 416-20, 2015.

38. Fang $M$, Zhong XY, Du B, Lin CL, Luo F, Tang LJ and Chen J: Role of DJ-1-induced PTEN down-regulation in migration and invasion of human glioma cells. Chin J Cancer 29: 988-994, 2010

39. Ismail IA, Kang HS, Lee HJ, Kim JK and Hong SH: DJ-1 upregulates breast cancer cell invasion by repressing KLF17 expression. Br J Cancer 110: 1298-1306, 2014.

40. Zhu ZM, Li ZR, Huang Y, Yu HH, Huang XS, Yan YF, Shao JH and Chen HP: DJ-1 is involved in the peritoneal metastasis of gastric cancer through activation of the Akt signaling pathway. Oncol Rep 31: 1489-1497, 2014

41. Li Y, Cui J, Zhang CH, Yang DJ, Chen JH, Zan WH, Li B, Li Z and He YL: High-expression of DJ-1 and loss of PTEN associated with tumor metastasis and correlated with poor prognosis of gastric carcinoma. Int J Med Sci 10: 1689-1697, 2013.

42. Gupta A and Dey CS: PTEN, a widely known negative regulator of insulin/PI3K signaling, positively regulates neuronal insulin resistance. Mol Biol Cell 23: 3882-3898, 2012.

43. McNally RS, Davis BK, Clements CM, Accavitti-Loper MA, Mak TW and Ting JP: DJ-1 enhances cell survival through the binding of Cezanne, a negative regulator of NF-kappaB. J Biol Chem 286: 4098-4106, 2011.

44. Ismail IA, Abdel Shakor AB and Hong SH: DJ-1 protects breast cancer cells against 2'-benzoyloxycinnamaldehyde-induced oxidative stress independent of Nrf2. J Cell Physiol 230: 2262-2269, 2015.

45. He X, Zheng Z, Li J, Ben Q, Liu J, Zhang J, Ji J, Yu B, Chen X, Su L, et al: DJ-1 promotes invasion and metastasis of pancreatic cancer cells by activating SRC/ERK/uPA. Carcinogenesis 33: 555-562, 2012

46. Chang AY and Wang M: Molecular mechanisms of action and potential biomarkers of growth inhibition of dasatinib (BMS-354825) on hepatocellular carcinoma cells. BMC Cancer 13: 267, 2013. 
47. Li Y, Drabsch Y, Pujuguet P, Ren J, van Laar T, Zhang L, van Dam H, Clément-Lacroix P and Ten Dijke P: Genetic depletion and pharmacological targeting of $\alpha \mathrm{v}$ integrin in breast cancer cells impairs metastasis in zebrafish and mouse xenograft models. Breast Cancer Res 17: 28, 2015.

48. Kim SA, Kwon SM, Kim JA, Kang KW, Yoon JH and Ahn SG: 5'-Nitro-indirubinoxime, an indirubin derivative, suppresses metastatic ability of human head and neck cancer cells through the inhibition of Integrin $\beta 1 /$ FAK/Akt signaling. Cancer Lett 306: 197-204, 2011.

49. Li Q, Tang Y, Qin J, Yi L, Yang Y, Wang J, He J, Su Q and Tan H: Subcellular localization of DJ-1 in human HL-60 leukemia cells in response to diallyl disulfide treatment. Mol Med Rep 14: 4666-4672, 2016.

50. Ceppi P, Papotti M, Monica V, Lo Iacono M, Saviozzi S, Pautasso M, Novello S, Mussino S, Bracco E, Volante M and Scagliotti GV: Effects of Src kinase inhibition induced by dasatinib in non-small cell lung cancer cell lines treated with cisplatin. Mol Cancer Ther 8: 3066-3074, 2009.

51. Sánchez-Bailón MP, Calcabrini A, Gómez-Domínguez D, Morte B, Martin-Forero E, Gómez-López G, Molinari A, Wagner KU and Martín-Pérez J: Src kinases catalytic activity regulates proliferation, migration and invasiveness of MDA-MB-231 breast cancer cells. Cell Signal 24: 1276-1286, 2012.
52. Koppikar P, Choi SH, Egloff AM, Cai Q, Suzuki S, Freilino M, Nozawa H, Thomas SM, Gooding WE, Siegfried JM and Grandis JR: Combined inhibition of c-Src and epidermal growth factor receptor abrogates growth and invasion of head and neck squamous cell carcinoma. Clin Cancer Res 14: 4284-4291, 2008.

53. Wang SE, Xiang B, Zent R, Quaranta V, Pozzi A and Arteaga CL: Transforming growth factor beta induces clustering of HER 2 and integrins by activating Src-focal adhesion kinase and receptor association to the cytoskeleton. Cancer Res 69: 475-482, 2009.

54. Sun B, Meng J, Xiang T, Chen Z, Li Y, Lu L, Zhang S and Chen X: Jianpijiedu fang improves survival of hepatocarcinoma mice by affecting phosphatase and tensin homolog, phosphoinositide 3-kinase, and focal adhesion kinase. J Tradit Chin Med 33: 479-485, 2013.

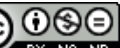

This work is licensed under a Creative Commons Attribution-NonCommercial-NoDerivatives 4.0 International (CC BY-NC-ND 4.0) License. 